\title{
Local Industrial Applications of Bentonite Deposits from Afar-Ethiopia
}

\author{
Wondafrash Mammo Ghebre* \\ Research and Development Directorate, Ministry of Mines and Petroleum, Ethiopia \\ *Corresponding Author: Wondafrash Mammo Ghebre, Research and Development Directorate, Ministry of Mines and Petroleum, \\ Ethiopia.
}

Received: June 18, 2019; Published: September 20, 2019

DOI:_10.31080/ASAG.2019.03.0652

\begin{abstract}
Bentonite is used mainly in the decolorizing of edible oils, although smaller amounts are used in well-drilling, for wine clarification and, possibly, foundry use. Edible oil processing probably accounts for $90 \%$ of bentonite consumption. Currently, there are numerous small-scale edible oil producers in Ethiopia who do not bleach their products, but forthcoming government regulations may make this mandatory. This should lead to an increase in demand for bleaching-grade bentonite. There is no domestic production of bentonite.

It is recommend locally available quality Bentonite occurrence with a standardized requirement as a raw material input for various industrial application based on laboratory test results.

Two previously known occurrences, namely, Warssiso, and Gewane areas, located in the Afar National Regional States, North Eastern part of Ethiopia are selected. Bulk and Channel sampling is proposed on the two potential areas to conduct mineralogical, chemical and geotechnical quality control methods, to determine the suitability for various industrial applications.

Keywords: Bentonite; Warssiso; Ledi
\end{abstract}

\section{Introduction}

Description of the study area and data sets

For geologists, bentonite is the name given to deposits consisting of minerals of the smectite clay group. By definition, clays are extremely fine-grained and at the microscopic level made up of flat or layered shaped minerals. The peculiar way smectite's chemical compounds are stacked give the individual crystals a negative charge along the flat surfaces. Electrical neutrality is maintained by cations (positively charged ions) that sit between the layers. The nifty feature is that the cations will exchange with other positively charged ions depending on the chemical setting.

For industrial chemists the interest is in the unique 'scavenging' property resulting from the large surface area of cation exchange in smectite clays. Also exciting is its habit of swelling in water giving bentonite an ability to strongly modify the flow behaviour of liquids. These unique properties open up an impressive range of industrial applications for both the 'scavenging' and 'swelling' forms of bentonite. Oil drillers add bentonite to their drilling liquid to prevent blowouts, wearers of cosmetics will find it as a base to mascara, the mud in a 'facial' is typically bentonite, others swear to the internal cleansing power from eating calcium bentonite, and cats too will find it in their kitty-litter.

Ethiopia's unique geological setting sitting astride the northern end of Africa's Great Rift Valley has not only given rise to its coffeehosting tropical highlands but also to these valuable clay deposits. Bentonites here formed by the chemical alteration of volcanic ash in the presence of water such as in a lake. Such a unique volcanic setting has been provided by the spreading of tectonic plates along the East African Rift. Deposits are found in Afar in the north and in southern Ethiopia as well [1].

Bentonitic clay resources are found in the Afar National Regional State and Southern Peoples, Nations and Nationalities Regional State. The Afar region Bentonite occurrences are easily accessible, as they are located near the main road. The main occurrences in afar are located at Warssiso, Hadar, Gewane and Ledi.

The Warssiso Bentonite deposit located 500 Km Addis AbabaSemera main road and 0.7 Km-3.0 Km towards north, between Badona river and Warseiso. Gewane bentonite deposit $15 \mathrm{Km}$ NNE of Gewane town, at which Gewane itself is $376 \mathrm{Km}$ north east of Addis Ababa - Semera main road.

\section{Warssiso deposit}

- Warsisa is south west of the town of Mile, Afar. It is located approximately 6 kilometres from the turn off from the highway to Addis Ababa along the Mile to Dessie road.

- The Bentonite deposit of Warssiso is well exposed forming the back of a dry creek that is a tributary of the Awash River. The bentonite layer is overlain by loamy gravel and sandy clay.

- The bentonite at Warssiso has a variety of colour. At some points it is light-grey or tending to a dark yellowish color. It is the laterally compacted/welded altered volcanic ash. It is very smooth and lateral sample surfaces have a distinctive soapy feel. 
- Previous analysis of Warssiso bentonite indicates it a calcium bentonite.

- Three (3) samples were taken from Warssiso deposit from two (2) locations.

- Sample 3 is darker than that of Sample 1 and 2.

\section{Ledi deposit}

- The second place we took bentonite samples is called Ledi. Ledi is along the main asphalt highway to Addis Ababa to Afar, south of the town of Mile.

- The Ledi deposit was less layered than Warsissa deposit and contained salt filled fractures.

- From previous analysis it is known that Ledi Bentonite is sodium bentonite.

- The Ledi bentonite deposit is exposed on the both sides of the main road.We took bentonite samples from both sides of the main road as it passes through the Ledi deposit.

- One (1) sample was taken from the east side deposit and two

(2) samples were taken from the west side deposit, north of the Awash River.

The research focuses on Warssiso and Ledi Bentonite Occurrences.

\begin{tabular}{|l|c|c|}
\hline & $\mathbf{X}$ & $\mathbf{Y}$ \\
\hline Warseissso (Mille) & $40^{\circ} 39^{\prime} \mathrm{E}$, & $11^{\circ} 22^{\prime} 20^{\prime \prime} \mathrm{N}$ \\
\hline Ledi & $40^{\circ} 41^{\prime} \mathrm{E}$, & $11^{\circ} 09^{\prime} 30^{\prime \prime} \mathrm{N}$ \\
\hline
\end{tabular}

Table a

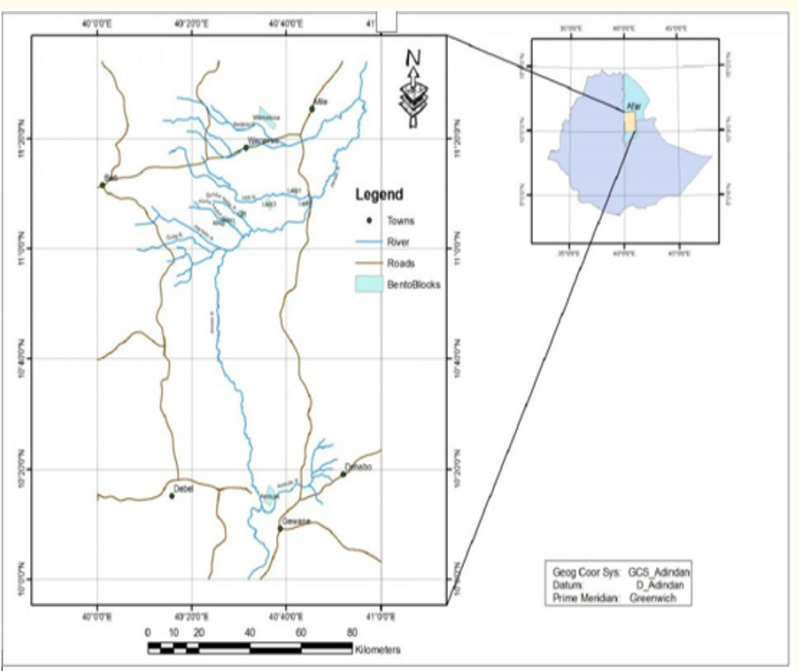

Figure a: Bentonite occurrence map of Afar area (After Tibebu M et.al., 1983).

\section{Methodology}

Research methodology

The successive steps of methods to be employed are as follows;

- Literature review and market study

- Field work phase

- Laboratory tests

- Flow sheet procedure for Bentonite
Literature review and market study

A primary source of information was referred

- Mengistu and Fentaw [2] Industrial Minerals and Rocks Resource Potential of Ethiopia,

- Demand and supply survey of Ethiopia industrial minerals sub-sector [3].

- Indu. mine and Artesinal mining study report; Key Worth, Nottigham, British Geological Survey [4].

- A Bentonitic clay around Mille and Gewane, Wollo and Harrarghe Adm. Region,

- Characterization and Beneficiation of Bentonite Deposit, Warseisso.

- Import data of Bentonite for the last five years is as follows, (2009-2013) was considered [5].

Field work phase

- Bulk and Channel sampling on selected areas of Bentonite

- $\quad$ GPS reading of the sampling points

\section{Laboratory tests}

Mineralogical, Chemical and Geotechnical Quality Control methods

- $\quad$ Mineralogical analysis: To determine the mineral composition of the Bentonite samples

- $\quad$ Chemical analysis

To determine chemical composition of the Bentonite sample as to its applicability as bleaching oil, purification in Winery, and Water purification and sewage treatment and in chemical industries in carrier of catalyst, insecticides, pesticides and fungicides and in the filler of rubber and plastic industries.

\section{Geotechnical tests}

To determine applicability as drilling mud, foundry sand, Iron ore pelletizing of metallurgy industries and civil use and construction.

Flow sheet procedure for Bentonite

Appropriate beneficiation and flow sheet procedure for each application of Bentonite shall be recommended.

Description of the study area and data sets

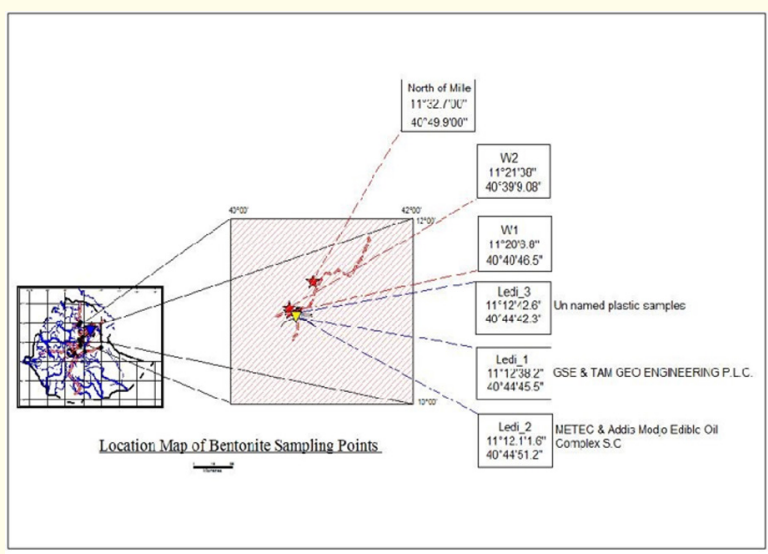

Figure b 


\section{Anticipated results}

Based on the laboratory result, recommendations of appropriate characterization, beneficiation and flow sheet procedure for each application of Bentonite shall be conducted.

\section{Significance of the proposed research}

The ultimate significance of the proposed research is "Import substitution" of Bentonite and consequently saving foreign currency.
Addis-Modjo Edible oil Complex factory, Awash Winery S.C, Basic metals Engineering (Metal Corp.), Drilling companies and Water sewerage authority will be potential partners for the proposed research and supposed to be possible beneficiary of the output of the research.

Accordingly the following table ( $\mathrm{x}, \mathrm{y}, \mathrm{z}$ ) illustrates the amount of samples submitted to the corresponding laboratories and the results received.

\begin{tabular}{|l|c|c|c|c|c|c|}
\hline & $\mathbf{X}$ & $\mathbf{Y}$ & Surface area ${\left(\mathbf{M}^{2}\right)}^{\prime}$ & Thickness (M) & Specific gravity & Reserve (MT) \\
\hline Warssis o (Mille) & $40^{\circ} 39^{\prime} \mathrm{E}$, & $11^{\circ} 22^{\prime} 20^{\prime \prime} \mathrm{N}$ & $1,265,155$ & 5.58 & 2.35 & 16 \\
\hline Ledi & $40^{\circ} 41^{\prime} \mathrm{E}$, & $11^{\circ} 09^{\prime} 30^{\prime \prime} \mathrm{N}$ & 557,500 & 3.2 & 2.35 & 4.2 \\
\hline
\end{tabular}

Table b

\section{Results accomplished}

Addis modjo edible oil complex S.C

Physical specifications

- $\quad$ Free moisture Max $10 \%$

- $\quad$ Loss on Ignition $7.2 \%$

- $\quad$ PH value $2.2-4.8$

- $\quad$ Free acid less or equal to $0.3 \%$

- Decoloriztion Ability greater than 90\%

- Filtration property:- good and speedy on filtration

- $\quad$ Particle size distribution:- less than 45 Micron $=60 \%$ and $45-75$ micron $=20 \%$

- Chemical analysis:- Sio265-70\% Fe2033.5\% K2O -1.9\% Mg0 2.2\%

Chemical composition

\begin{tabular}{|l|c|c|c|c|}
\hline No & Chemicals & $\begin{array}{c}\text { Composition (\%) } \\
\text { S.A.T. CoLtd, } \\
\text { China* }\end{array}$ & $\begin{array}{c}\text { Warssiso } \\
\text { (Mille) }\end{array}$ & $\begin{array}{c}\text { Addis- } \\
\text { Modjo S.C }\end{array}$ \\
\hline 1 & $\mathrm{SiO}_{2}$ & 68.4 & 51.38 & 61.96 \\
\hline 2 & $\mathrm{Al}_{3} \mathrm{O}_{3}$ & 14.3 & 14.36 & 8.24 \\
\hline 3 & $\mathrm{Fe} 2 \mathrm{O} 3$ & 3.6 & 8.66 & 3.35 \\
\hline 4 & $\mathrm{CaO}$ & 0.9 & 1.77 & 2.92 \\
\hline 5 & $\mathrm{MgO}$ & 2.2 & 2.63 & 1.59 \\
\hline 6 & $\mathrm{Na}_{2} \mathrm{O}$ & 0.6 & 2.07 & 0.05 \\
\hline 7 & $\mathrm{~K} 20$ & 1.9 & 1.19 & 0.01 \\
\hline 8 & $\mathrm{L.O.I}$ & - & 6.92 & 13.7 \\
\hline
\end{tabular}

Table c

*S.A.S.T. CoLtd, China $=$ Shenzhen Aoheng Science and Technology Co. Ltd, China.

Bleaching

\begin{tabular}{|c|c|c|c|c|c|c|c|}
\hline Oil Types & Color & $\begin{array}{c}\text { Before } \\
\text { Bleaching }\end{array}$ & $\begin{array}{c}\text { Warsisso } \\
\text { Bentonite }\end{array}$ & $\begin{array}{l}\text { Addis Modjo } \\
\text { Bentonite }\end{array}$ & \multicolumn{3}{|c|}{ Bleaching Efficiency (\%) } \\
\hline & & & & & $\begin{array}{l}\text { Warssiso } \\
\text { Bentonite }\end{array}$ & $\begin{array}{l}\text { Addis Modjo } \\
\text { Bentonite }\end{array}$ & $\begin{array}{l}\text { Company } \\
\text { Standard }\end{array}$ \\
\hline \multirow{3}{*}{$\begin{array}{l}\text { Cotton seed oil } \\
\text { Expeller }\end{array}$} & Yellow & 27 & 26 & 25 & 7.4 & 7.4 & Max,30 \\
\hline & Red & 4.0 & 3.6 & 3.0 & 10 & 25 & Max,3.0 \\
\hline & Blue & 0.2 & 0.2 & 0.2 & 0 & 0 & Nil \\
\hline \multirow{3}{*}{$\begin{array}{l}\text { Rapeseed seed oil } \\
\text { expeller }\end{array}$} & Yellow & 27 & 27 & 12 & 0 & 55.56 & Max,30 \\
\hline & Red & 3.3 & 3.0 & 1.3 & 9.1 & 60 & Max,3 \\
\hline & Blue & 0.4 & 0.2 & 0.2 & 50 & 50 & Nil \\
\hline
\end{tabular}

Table d

The role of fuller earth in edible oil manufacturing process include

- To remove the color from the neutralized and dried vegetable oil

- It separate pigments, colloid, impurities, some metals in the crude oil

- $\quad$ It reduces oxidants activity (by removing heavy metals)
- It is used to remove polar components like chlorophyll, carotinoids, phospholipids and peroxides

- $\quad$ For finishing and processing of soap

- It should have high filtration speed and food grade

- Much should be taken on the uniformity of bleaching earth

- $\quad$ Surface area of bleaching should be (320-375) $\mathrm{m}^{2} / \mathrm{gm}$ 
Awash winery

- The company recommend, In order to use in food industry, it is necessary to know its purity status and of course it is mandatory to have a certificate of analysis (COA) from a certified laboratory confirming its food grade.

- Bentonite is extremely fine, clay like material. It has a negative electrical charge, and it is used to remove positive charged particles from wine. Bentonite is most commonly used to remove excess protein from both white and blush wines. It is also used for clarification fining of white and blush wines, and sometimes bentonite is effective in clearing hazy fruit wines

- A normal dose is 1 to 2 grams of dry bentonite per gallon of wine. However, it is often used at dose levels that range from 1 to 4 grams per gallon. Bentonite can strip desirable aro- mas from wine when used in excessive amounts (more than 2grams per gallon) so beneath testing should always be done

- Bentonite should be mixed with water and allowed to stand for twenty four hours before being added to wine

- Bentonite can be mixed easily in a blender. Put the required amount of hot water in the blender turn the blender on and slowly add the dry powder. When the mixture is cool, place it in a refrigerator and allow the bentonite mixture of hydrate for at least $24 \mathrm{hrs}$. add the hydrated mixture to the wine slowly and stir continuously.

- $\quad$ Awash Winery S C conducted the required tests, and observed that the Warsieiso Bentonite can decolorize a liquid. There-

Geological survey laboratory, physical tests of warssiso bentonite

\begin{tabular}{|l|c|c|c|c|}
\hline Specific gravity $\left(\mathrm{g} / \mathrm{cm}^{3}\right)$ & $2.3-2.4$ & $\mathrm{~W}-01=1.90$ & $\mathrm{~W}-02=2.45$ & A little bit lower than the standard \\
\hline Free Swell $(\mathrm{ml})$ & $24-36$ & $\mathrm{~W}-01-27$ & $\mathrm{~W}-02=19.6$ & More or less within the standard \\
\hline Degree of Swelling in \% & & $170 \%$ & $100 \%$ & Below the standard \\
\hline Moisture content (mass \%) & 15 & $\mathrm{~W}-01-12.2$ & $\mathrm{~W}-02=9.22$ & Below the standard \\
\hline
\end{tabular}

Table e

Akaki basic metals industry (metech)

\begin{tabular}{|c|c|c|c|c|c|c|}
\hline $\begin{array}{c}\text { Samp. } \\
\text { no }\end{array}$ & Sample Type & $\begin{array}{c}\text { Bonding property } \\
\text { with } \mathbf{H}^{2} \mathbf{0}\end{array}$ & $\begin{array}{c}\text { Elastic } \\
\text { property }\end{array}$ & $\begin{array}{c}\text { After one day } \\
\text { bonding and } \\
\text { drying property }\end{array}$ & $\begin{array}{c}\text { After a few days } \\
\text { bonding and } \\
\text { drying property }\end{array}$ & $\begin{array}{c}\text { During pouring } \\
\text { time how to resist } \\
\text { molten metal }\end{array}$ \\
\hline 1 & Powder and Coarse & Very good & Very good & Very good & Very good & Very good \\
\hline
\end{tabular}

Table f

$50 \mathrm{~kg}$ Bentonite sample from Ledi area was submitted to Akaki Basic Metals Industry The result obtained is as follows

As can be seen from the result the Bentonite of Ledi area can be used for Moulding purposes.

Foundry grade parameters (Steel founders society of America-SFSA)

- $\quad$ Liquid Limit: 600-850

- $\quad$ Calcium Oxide: $<0.70 \%$

- Water Content: 6-12\%

- $\quad$ Ph Value: $>8.2$

- $\quad$ Swelling Volume: 28-32 Ml/2 Gm

Addis Ababa University

\section{Characterization}

Inductively Coupled Plasma Optical Emission Spectrometry, (ICP-OES) (Optima 3300 DV model) was used to determine chemical weight percent composition of the samples.

ICP elemental analysis result of Bentonite samples in weight \%

\begin{tabular}{|c|c|c|c|c|c|c|c|c|c|}
\hline Sample & Si & Al & Ca & Na & Mg & K & Fe & Ti & LoI \\
\hline B1 & 27.8 & 7.0 & 0.8 & 1.21 & 1.70 & 0.8 & 6.0 & 0.5 & 14.83 \\
\hline B3 & 23.9 & 8.0 & 1.2 & 1.56 & 1.41 & 1.3 & 6.9 & 1.0 & 12.84 \\
\hline BS2 & 32.0 & 5.9 & 0.2 & 0.07 & 1.36 & 0.3 & 0.9 & 0.1 & 16.18 \\
\hline BS4 & 29.4 & 7.2 & 0.9 & 0.81 & 1.28 & 0.6 & 0.9 & 0.1 & 11.79 \\
\hline \multicolumn{10}{|c|}{ Table g }
\end{tabular}

Thermal stability was carried out in air, with a Perkin-Elmer TGA 7 instrument in the temperature range of $20-900^{\circ} \mathrm{C}$ in the heating rate of $20^{\circ} \mathrm{C} / \mathrm{min}$. Loss of ignition is calculated from the total weight loss up to $900^{\circ} \mathrm{C}$. The thermal decomposition profile of the raw bentonite is very similar with a bit more water in the B1 sample. The main weight loss is observed at $110^{\circ} \mathrm{C}$ due to water molecules adsorbed in the materials. A minor weight loss is observed at higher temperature $\left(500^{\circ} \mathrm{C}\right)$ in both cases due to the dehydroxilation produced upon the decomposition of the layered structure. This later weight loss is less pronounced in the standard BS2 sample, and it is shifted to higher temperature $\left(700^{\circ} \mathrm{C}\right)$ in the BS4 standard. In the later case, this means that the Bentonite has been treated, probably thermally treated, in order to make it more stable for further application. This BS4 sample is also showing the 
lowest amount of water loss at lower temperature indicating that somehow this sample is less hygroscopic than the others.

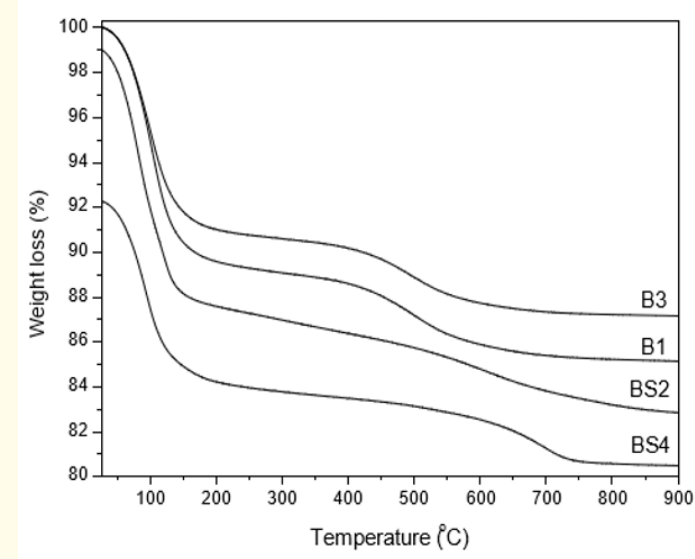

Figure c

The raw Bentonite samples B1 and B3 used in this study were collected from Warssiso (Mille) and Ledi (Afar), respectively. For comparison purposes we study two standard bentonites imported from Mojo Oil Factory (BS2) and Awash Winery (BS4).

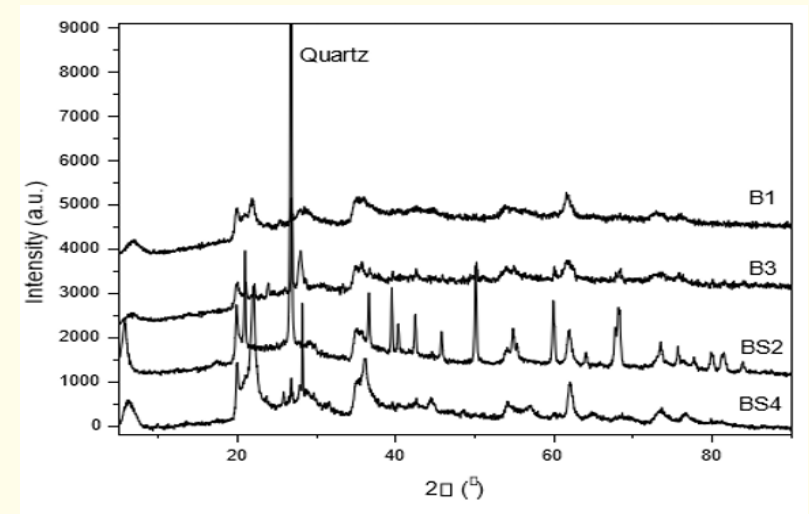

Figure d

$\mathrm{X}$ ray Diffraction is done for the identification of crystalline phases. Powder X-ray diffraction (XRD) patterns were collected with a Philips X'PERT diffractometer equipped with an X Celerator detector and using $\mathrm{Cu} \mathrm{K} \alpha$ radiation.

When observing the XRD profiles. The intensities in samples B1 and B3 show their amorphous nature, despite the presence of layered materials, the percentage of crystalline phases must be low, and besides, may be in small particle size. On the other hand the XRD pattern of BS4 shows an increase in crystallinity while maintaining the same profile than B1 and B3. This could be corroborating that this sample has been calcined to certain extend to produce condensation of layers or to enhance crystallization of amorphous phases, or leading to the sintering of small particles to yield larger crystalline domains. These three possible mecha- nisms could be further studied by scanning electron microscopy if required. In any case, the three samples show the typical profile of natural bentonite. In the case of the standard BS2, the pattern is completely different showing intense peaks of a crystalline phase that has been identified as alpha quartz as main phase. This sample was also showing a different TGA profile thus we did not continue with further studies since it seems a highly mixed sample with low content of bentonite [6].

\section{Applications proposed by AAU}

Upon studying of some of the above mentioned parameters, further conclusions can be made in this regard. For now, we have tested the two raw bentonites in the following chemical applications:

1. As starting material for the synthesis of Zeolite A for detergents. The results are not promising since the process would require extra addition of a silicon source. This is out of the question because there is an alternative source, kaolinite, which yields the desired Zeolite without any extra chemical.

2. For Fluoride removal. As they are, the bentonites do not have enough capacity to remove fluoride from water (they are cation exchangers), however, we are now studying the possibility of using them as a support to prepare high capacity materials for $\mathrm{F}$ removal (anion exchangers). The role of the bentonite in this case would be that of providing with mechanical strength without scarifying F removal capacity. This is a work in progress, we hope to have further details by the end of the Ethiopian year.

3. In waste water treatments to remove the Chromium (III or VI) after the tanning process in the leather factories. We have obtained up to $90 \%$ removal of $\mathrm{Cr}$ (VI) using bentonite B1, further studies using real waste water provided by LIDI (Leather Industries D Institute) shows no good performance in the removal of $\mathrm{Cr}$ (III).

4. In the same direction and taking advantages of a new linkage with LIDI, we believe that bentonites could be used in the treatment of solid wastes generated in the first step of the manufacturing of leather. For this purpose, further contact and official linkage should be established with LIDI environmental protection laboratory.

5. Quality valuation of bentonite as product of the pozzolanic cement. Pozzolanic properties are determined by means of comparison between calcium hydroxide content inside watery solution in contact with hydrated cement and the calcium hydroxide content necessary to obtain another watery solution saturated, and equally alkaline. The assay can be positive if calcium hydroxide concentration in solution is lower than the concentration of saturation (standard UNEEN 1965:2006). Pozzolanic cements are composed by Clinker, pozzolan and gypsum. The pozzolan content changes between 30 and 50 percent [6-10]. 


\section{Bibliography}

1. http://voices.nationalgeographic.com/2014/12/07/ethiopiasbentonite-trail-a-development-path/

2. Mengistu and Fentaw. "Industrial Minerals and Rocks Resource Potential of Ethiopia” (2003).

3. DJ Morgan. "Demand and supply survey of Ethiopia industrial minerals sub-sector". British Geological Survey Key Worth, Nottigham (2007).

4. DJ Morgan. "Indu. mine. and Artesinal mining study report". British Geological Survey Key Worth, Nottigham (2007).

5. www.ERCA.Com

6. Ministry of Mines, Research and Development Directorate, Addis Ababa, Ethiopia; (2) Fundación Gomez Pardo-ETSIME; (3) Escuela Técnica Superior de Ingenieros de Minas y Energía de Madrid- ETSIME; (4): Instituto de Catálisis y PetroleoquímicaCSIC Spain,Addis Ababa, February (2015).

7. A G Gunn., et al. "Inves. promotion study, Ethiopia World Bank Energy Access Project". British Geological Survey (2007).

8. Malis Eduard and Tibebu Mengistu. Report on Bentone around Mille and Gewane, Wollo and Harrarghe Adm. Region, EIGS, Addis Ababa, unpublished report (1983).

9. Mesfin Tesema. Bentonite Promotion Document, Occurrence of Bentonite in Ethiopia, EIGS, Addis Ababa, unpublished report (2012).

10. Saba Hadis., et al. Characterization and Beneficiation of Bentonite Deposit, Warseisso, Ethiopia, EIGS, Addis Ababa, unpublished report (2002).

\section{Volume 3 Issue 10 October 2019}

(C) All rights are reserved by Wondafrash Mammo

\section{Ghebre.}

